\title{
Gender and Mathematics Education Revisited
}

\author{
Gilah C. Leder
}

\section{Introduction}

Beginning in the early 1970s, systematic documentation in many countries of subtle, yet consistent gender differences in mathematics performance and participation in post compulsory mathematics courses in favor of males served as a catalyst for action. In these settings, new legislation and special interventions were introduced to redress demonstrated achievement disparities in mathematics. An important aim of the panel session was to describe the current situation in countries where gender equity is enshrined in legislation at the political level, and, by drawing on recent research and contemporary data gathering tools, to document whether or not inequities have been removed in practice or continue to exist in countries where concern and action about gender differences in mathematics learning have a long standing history.

There are also a significant number of countries where gender and mathematics learning issues have typically been ignored, are still not well recognized by their governments or valued in the wider community. To document the situation in those countries and highlight what progress has been made in those settings were also central aims of the panel's presentation.

The notions of gender parity and gender equality are a unifying thread weaved throughout the presentation. The former is described by UNESCO (2012) as "aim (ing) at achieving equal participation for girls and boys in education", while

gender equality is understood more broadly as the right to gain access and participate in education, as well as to benefit from gender-sensitive and gender-responsive educational environments and to obtain meaningful education outcomes that ensure that education

G.C. Leder $(\bowtie)$

Monash University, Melbourne, Australia

e-mail: Gilah.Leder@monash.edu 
benefits translate into greater participation in social, economic and political development of their societies. Achieving gender parity is therefore understood as only a first step towards gender equality. (UNESCO 2012, p. 21)

In brief, the areas covered in the session reflected the different perspectives and geographic diversity of the panelists. Attention was given to regions where issues about gender and mathematics education remain barely on the agenda and relatively little is known outside those countries about work and research that have been undertaken. The more widely disseminated research findings and common assumptions about gender and mathematics learning, based on research particularly in Western countries, were also revisited and updated.

The order of presentations was part of our overall message. We therefore started off with presentations from regions where gender and mathematics is not widely seen as a primary issue of concern and/or about which relatively little is known in Western countries — whose research is disseminated widely — and moved to surveys of areas where gender equity is enshrined in legislation at the political level, but in practice inequities continue to exist.

To begin, data referring to India were presented by Jayasree Subramanian. This was followed by Nouzha El Yacoubi whose presentation also covered a large region where concern and progress re-gender and mathematics are still not well known or recognized in the wider research community, and then by Maria Trigueros Gaisman who focused on Mexico. The final three presentations also covered wide geographic areas, in alphabetical order: Australia, Europe, and the United States. Pertinent research and issues were presented respectively by Helen Forgasz, Lovisa Sumpter and Sarah Lubienski.

Each panelist sketched realities, achievements, and outcomes in mathematics education and gender in the area in which she lives and works and of which she has first hand knowledge. Reference was also made to examples of dissonance between theory and practice with respect to mathematics education and gender. Highlighted, too, were pressing next step(s) to improve the situation in the context represented by each speaker. If translated into a realistic and focused research agenda, and if taken up, these steps can move the field forwards.

\title{
Reference
}

UNESCO (2012). World atlas of gender equality in education. Paris: Author.

\section{Gender and Mathematics Education in Africa}

\author{
Nouzha El Yacoubi \\ University Mohammed V Rabat-Agdal. Morocco \\ e-mail: n.elyacoubi@yahoo.fr; nelyacoubi@fsr.ac.ma
}




\section{Introduction}

Even in the developed countries, where equity in Education was reached a long time ago, the rates of enrollment of girls in mathematics courses are relatively low. The gender problem and mathematics education has been studied since 1970 and some factors of that representativeness have been identified, in particular in the developed countries. But this area of research is still unexplored in the developing countries. In Africa, specifically, little research has been done until now on Gender and mathematics education despite the millennium goals recommending equity in education and the encouragement of African females to choose mathematics studies and to embrace scientific and technological careers.

Nevertheless, the role of women in the scientific development of Africa has been definitively recognized as a crucial and determining factor in building and reinforcing the continent's scientific and technological capacities, because no African country can afford to leave $50 \%$ of its population, out of its development process.

It is evident that Education in general in Africa was, and is till now, seriously affected by poverty, but with respect to the education of girls, history, religion and culture were, and they remain, important influencing factors.

These socio-cultural barriers are more pronounced when they come to scientific, technical and vocational education and, are unfortunately, tragic when they concern mathematics education.

\section{The Current Situation in Africa}

According to the UNESCO Institute for Statistics report published in September 2010, the lowest literacy rates were observed in sub-Saharan Africa, where the adult literacy rate for males is 71.6 and $53.6 \%$ for females and in Northern Africa it is respectively 76.7 and $58.1 \%$. It should be highlighted that more than half of the adult population is still illiterate in the ten following countries: Gambia (55\%), Senegal (58 \%), Benin (59 \%), Sierra Leone (60\%), Guinea (62\%), Ethiopia $(64 \%)$, Chad (67\%), Burkina Faso (71\%), Niger (71\%), and Mali (74 \%).

The net enrolment ratio in the primary school age population in sub-Saharan Africa countries is around $52.3 \%$ girls (and $60.7 \%$ boys), except in a very few countries where almost all girls of primary school age are enrolled at schools.

But there is a substantial drop out among girls at the secondary school level; it is due to socio-cultural (early marriage), financial reasons, institutional barriers and poor performance of girls. The Trends in Mathematics and Science Study (TIMSS) reported that between 68 and $90 \%$ of African students in grade eight failed to reach the low benchmark in mathematics (IEA 2003). And unfortunately no significant progress was registered in TIMSS 2007. It is a pity that Africa was so poorly represented in such an important international assessment of the mathematics and science knowledge of fourth and eighth grade students. For example in TIMSS 
2007, only six African countries have participated among 59 Countries namely: Algeria-Botswana-Egypt-Ghana-Morocco and Tunisia, and there was no African country among the 8 Benchmarking participants. The African countries participating in TIMSS 1995 through 2007 are as follows:

\begin{tabular}{l|l|l|l|l|l|l|l}
\hline \multirow{2}{*}{ Country } & \multicolumn{9}{l}{ Grade 4 } & \multicolumn{5}{l}{ Grade 8 } \\
\cline { 2 - 8 } & 1995 & 2003 & 2007 & 1995 & 1999 & 2003 & 2007 \\
\hline Algeria & & & $\mathrm{x}$ & & & & $\mathrm{x}$ \\
\hline Botswana & & & & & & $\mathrm{x}$ & $\mathrm{x}$ \\
\hline Egypt & & & & & & $\mathrm{x}$ & $\mathrm{x}$ \\
\hline Ghana & & & & & & $\mathrm{x}$ & $\mathrm{x}$ \\
\hline Morocco & & $\mathrm{x}$ & $\mathrm{x}$ & & $\mathrm{x}$ & $\mathrm{x}$ & $\mathrm{x}$ \\
\hline Tunisia & & $\mathrm{x}$ & $\mathrm{x}$ & & $\mathrm{x}$ & $\mathrm{x}$ & $\mathrm{x}$ \\
\hline
\end{tabular}

As for upper secondary school, the enrollment ratio of girls is just about $17 \%$ in Sub-Saharan Africa, so only a few girls have the opportunity to be enrolled in scientific classes, and among that population very few choose Mathematics courses. The best registered percentage for enrollment of girls in Mathematics at that level is about $30 \%$ (Huggins and Randell 2007) and this percentage decreases with grade level and is about $10 \%$ for the tertiary level.

\section{The Causes}

The factors identified in contributing to the gender problem in mathematics education in the developed countries remain valid for Africa, but other factors should be added like negative socio-cultural attitudes, household tasks at home, gender biased curriculum, poor didactic materials, lack of school facilities (dormitories), lack of sponsorship, unmotivated and unqualified mathematics teachers, lack of moral and financial parental support, lack of self confidence among the girls, poor performance in exams, and so on.

\section{Interventions Introduced}

First, the African Union (UN) has set up mechanisms and special committees at the ministerial level for monitoring progress towards attainment for Education For All (EFA). Gender mainstreaming has been identified and adopted as a strategy for achieving gender equity. In particular, special projects were launched with the aim of increasing the enrollment of African girls in Science, mathematics and technology, and to encourage African women to embrace scientific and technological careers. The programs included: "Special Project on Scientific, Technical and 
Vocational Education of Girls in Africa in the framework of the UNESCO's Medium-Term Strategy" (1996-2001); “Africa's Science and Technology” project launched in 2007 by the African Union Summit of the Heads of State and Government; "Africa and Gender Equity" including "Science, technology and engineering education" in the UNESCO Medium-Term 2008-2013, as well as other initiatives sponsored by the World Bank, USAID, NEPAD (New Partnership for Africa's Development), UNICEF, and some non-governmental organizations (NGO's).

A special program for reducing gender disparities in science, technology and innovation has also been undertaken by the United Nations Economic Commission for the East African Community member countries. This, Huggins and Randell (2007) advocated, should serve as a case study for the other African regions.

There have been various other activities, for example, international conferences on Gender, Science and Technology were held in: Beijing (1995), Arusha (1997), Harare (1997) where national surveys of 21 African countries, assessing the participation of girls and women in scientific education and vocational training, were given, (Hoffmann-Barthes and Malpede 1997), Dakar (2000), Cairo (2006), Bamako and Ségou (2009), Paris (2010): UNESCO Expert Group Meeting.

Some camps and competitions for African girls have been organized through Africa, including: Camp of Excellence in Sciences and Mathematics for Young African Girls held, since 2000, in Mali and other African countries; Girls STEM (Science, Technology, Engineering and Mathematics) Camp initiative (Abuja 2011), Miss Mathématique (created in Ivory Coast and recently in Benin) and so on.

\section{Conclusion and Suggestions}

Despite these initiatives, females' participation in Africa, in Science, and Technology, and in particular in Mathematics, from primary through tertiary education to the career level is still very low. This could be explained by, among other factors, the persistent socio-cultural barriers, lack of clear policy guidelines for increasing the rates of enrollment of African girls in mathematics, lack of assessment and follow up of the various undertaken initiatives, lack of gender analysis expertise and so on.

A valorized image of African women in mathematics education and mathematics careers should be promoted and gender stereotypes with regard to mathematics careers should be countered by parents, teachers and all other actors in the school and societal environments.

Interventions for females should aim to achieve equity of outcomes rather than just equal access to educational opportunities in mathematics. So permanent assessment and relevant follow up are key elements in any undertaken initiative. 


\section{References}

Aiken, L. (1970). Attitudes Toward Mathematics, Review of Educational Research, 40(1): 551-596.

Fennema, E. and Sherman, J. (1977). Sex-related differences in mathematics achievement, spatial visualisation and affective factors, American Educational Research Journal, 14(1): 51-71.

Walden, R. and Walkerdine, V (1985). Girls and mathematics. London: University of London.

Burton, L. (1990). Gender and mathematics: An international perspective. London: Cassell.

Kaiser-Messmer, G. (1993). Results of an empirical study into gender differences in attitudes toward Mathematics, Educational Studies in Mathematics, 25(3): 209233.

Fennema, E.L and Leder, G (1995). Mathematics and Gender. New York: Teacher College Press.

Kiania, A.M. (1995). Gender and mathematics achievement parity: Evidence from Post-Secondary Education. Vol. 116 (4) p.586 - 591

B.Grevholm and G.Hanna (1995). Gender and Mathematics Education. Sweden, Lund University Press

Lamb, S (1997). Gender difference in mathematics participation: An Australian participation. Vol. 23(1); pp.105 -115.

Hoffmann-Barthes, \& Malpede (1997). Scientific, technical and vocational education of girls in Africa. Retrieved from http://www.unesco.org/education/.../ girls/reports.pdf

Working document1999 of UNESCO : Scientific, technical and vocational education for girls in Africa

TIMSS 2003 International Report on achievement in the Mathematics Cognitive Domain IEA (2004). Retrieved from http://timss.bc.edu/pdf/t03_download/ t03mcogdrpt.pdf

Xin Ma (2004). Current Trend in Gender Differences in Mathematics Performance: An International Update. ICME 2004, TSG 26.

Asimeng-Boahene, L (2005). Gender Inequity in Science and Mathematics Education in Africa: The Causes, Consequences and Solutions. Education, Vol. 126, No. 4, PP. 711-72

Huggins, A., \& Randell, S.K. (2007). Gender Equality in Education in Rwanda: What is happening to our girls? Retrieved from http://www.nuffic.nl/ international-organizations/international-education-monitor/country-monitor/ africa/rwanda/documents

D. Fisher, R. Koul\&S. Wanpen (2008): Science, mathematics and technology Education:Beyond cultural boundaries. $5^{\text {th }}$ SMTE Proceeding

V.S Mullis, M.O Martin and P.Foy (2008). TIMSS 2007 International Report. Retrieved from http://www.timss.bc.edu/timss2007/intl_reports.htm 
Roland G. Fryer, Jr and Steven D. Levitt (2009). An Empirical Analysis of the Gender Gap in Mathematics. NBER Working Paper No. 15430. JEL No. I20

N.M. Else-Quest, J.S. Hyde and M.C.Linn (2010). Cross-National Patterns of Gender Differences in mathematics. A Meta-Analysis. Psychological Bulletin, Vol 136. No 1, 103-127.

UNESCO Institute for Statistics (2010). Adult and youth literacy: global trends in gender parity. UIS Fact Sheet. (September, 2010, No. 3).

United Nations. Economic and Social Council. Commission for Africa (2011). Mainstreaming gender in Science, Technology and Innovation Systems in the East African Community. Retrieved from http://www.uneca.org/.../codistiireportexecutivesumma

Hanna David (2011). Overcoming the gender gap in math, Science and technology: A $21^{\text {st }}$ Century View. Journal of Education and Social Research. Vol (1).

Nouzha El Yacoubi (2011). Problème du Genre et Mathématiques en Afrique. EDIMath, IMU-CANP, ICMI workshop, Bamako September 2011. (Could be provided by the author : n.elyacoubi@yahoo.fr)

\section{Gender and Mathematics Education in Mexico}

María Trigueros Gaisman

Instituto Tecnológico Autónomo de México, ITAM

e-mail: trigue@itam.mx

\section{Introduction}

In the area of Mathematics Education in Mexico, research on gender has produced interesting findings. Some studies have analyzed gender differences in relation to results attained on performance tests, while others have focused on more specific topics, such as spatial visualization, the differential relations that mathematics teachers may establish with female and male students at various educational levels, the distinct attitudes of girls and boys towards mathematics and towards the use of technology as an aid in teaching and learning mathematics.

At the same time there has been an emerging trend on the development of educational policies to reduce the gender gap in education at all levels, and to foster equity in academic work. 


\section{Results of Gender Studies at Elementary Education}

Since the first study (Bosch and Trigueros 1996) no substantial gender differences have been observed in different tests in primary school (González 2003; Rivera 2003; Ursini, et al. 2010). However, PISA results indicate that gender differences favoring boys appear in the transition to secondary school. Studies on students' attitudes towards the subject (Ursini et al. 2004, 2007; Campos 2006; Ursini and Sánchez 2008; Ursini 2010) show that self-confidence favoring boys, and perception of mathematic as a male domain, start to develop at around 13 years of age, with boys attributing good performance to intelligence or skills and girls to effort and obedience. Interestingly, teachers were found to characterize differences in children's performance in the same terms (Ramirez 2006; Ramirez and Ursini 2008).

Regarding the use of technology in the learning of Mathematics, Ursini and Sánchez (2008) found that boys held a pragmatic view of technology while girls considered it as a resource to construct knowledge. They found that the use of technology helped to develop positive attitudes towards mathematics, particularly among girls, and suggested that using technology with guiding activities to foster group-work and discussion, helped to modify certain cultural patterns of conduct which can foster equity.

The use of technology also modified teachers conception of Mathematics learning (Trigueros and Lozano 2008; Rodriguez and Ursini 2008) with females focusing more on exploration and investigation to develop students' self-confidence, independence and creativity and males on developing skills needed by students to move forward in their education.

\section{Results of Gender Studies at Higher Education}

As at the elementary school level, in higher education no specific gender differences have been found in different studies in mathematics grades and the gender inequality in access to higher education detected in earlier studies (Bosch and Trigueros 1996) has been constantly decreasing. The largest university in Mexico reported in 2009 (Saavedra 2010) that the percentage of female students was larger than that of male students and that graduation percentages also favored women (56\% of women graduated against $50 \%$ of men). However, there is still a severe under-representation of women in mathematics. Only $38 \%$ of women enroll in mathematics programs, and $43 \%$ of all students who graduate from these programs are women. The gender gap is greater when considering access to post-graduate education. In 2008 only $30 \%$ of students in postgraduate programs were women, although in programs related to mathematics education female students comprised $45 \%$. 
In a study involving university professors (Espinosa 2007), it was found that they considered male students to be more proficient in mathematics than females. They expressed the same beliefs as those found among teachers in elementary school about women being successful in mathematics because of their effort and discipline. Observation of classes detected a more passive attitude of female students and a tendency of male students to be more participative.

Although results show that, in general, female students are more perseverant in their studies, it seems that they still consider mathematics as a male domain, too competitive for women and that professors' beliefs tend to reinforce this conception.

\section{Results of Gender Studies on Faculty}

In the last few years there has been a large increase in the academic profession in Mexico, but problems related to gender in the access to work at universities are still present. Only $40 \%$ of professors are women. This gap widens in the case of mathematics departments where women represent less than $25 \%$ of all professors and many of them work in mathematics education (Saavedra 2010).

In terms of research, according to 2009 data from the National System of Researchers, women researchers in the area corresponding to physics and mathematics, which is the largest area of the system, represent only $19 \%$ of all researchers with $23 \%$ of them investigating in mathematics. Percentages of female researchers diminish as levels related to productivity rate increase, with only $3 \%$ of women at the top level.

Some of these differences can be related to perception of mathematics as an occupation which is difficult to combine with family life, but results show gender as a determinant of the choice of mathematics as a field of study independently of school achievement.

\section{Policies to Reduce the Gender Gap and Stereotypes}

The ministry of Education has developed several initiatives since 2008 to incorporate the gender perspective in all the educational programs to help to change stereotypes that contribute to gender inequity. Among the more important are a revision of content of all the mandatory primary school textbooks from a gender perspective to foster a change in socio-cultural patterns, and the distribution of books on gender equity and prevention of violence for teachers and students. Together with international organizations, the ministry has developed projects for school communities where people participate in activities designed to reflect on gender stereotypes and their change. Technology is used to show different behavior 
patterns in particular situations together with questions asking users to reflect, comment and discuss if they find those behaviors appropriate or not and why.

A revision of the published policies from different universities in Mexico reveals that in the last 10 years there has been an increase in policies intended to foster women's access to higher education and to reduce the barriers for female faculty. Most of the universities nowadays have developed innovative programs to reduce inequalities for women researchers, teachers and students. These include mandatory seminars to discuss gender issues, awards designed for women faculty and students and specific programs to recruit women as faculty. However, only a few of them have been designed specifically to increase the number of women researchers in STEM related careers or to strengthen the academic position of women researchers and their participation in academic activities.

Some of these policies have shown some positive impact, however, their implementation is unequal in different regions of the country, and some of them have had implementation problems in practice. The effective advancement of women as faculty, in particular, seems to be prevented by everyday practices that tend to ignore policies, or at least to apply them in a limited way.

\section{Conclusions}

This review of studies on gender and mathematics in Mexico shows that although some advance in reducing the gender gap in mathematics has been achieved, there is still much work to be done in terms of policies and programs to change sociocultural perceptions which inhibit the development of women in mathematics and mathematics related areas. More efforts are also needed to increase participation of women as faculty and as decision makers in areas related to mathematics, science and technology.

\section{References}

Bosch, C. \& Trigueros, M. (1996). Gender and mathematics in Mexico. In G. Hanna (Ed.). Towards gender equity in mathematics education. An ICMI Study. (pp. 277-284). Kluwer Academic Publishers, Dordrecht, Boston, London.

Campos, C. (2006). Actitud hacia las matemáticas: Diferencias de género entre estudiantes de sexto de primaria y tercer grado de secundaria. Unpublished Masters Thesis, Department of Mathematics Education, Cinvestav-IPN, México.

Espinosa, C. (2007). Estudio de las interacciones en el aula desde una perspectiva de género. Unpublished Masters Thesis, Department of Mathematics Education, Cinvestav-IPN, México.

González, R.M. (2003). Diferencias de género en el desempeño matemático. Educación Matemática. 15 (2), pp.129-161. 
Rivera, M. (2003). Diferencia de género en la visualización espacial: un estudio exploratorio con estudiantes de $2^{\circ}$ de secundaria. Unpublished Master Thesis, Department of Mathematics Education, Cinvestav-IPN, México.

Ramirez, M. P. and Ursini, S. (2008). Influence of the female teachers' gender vision on the type of interactions they establish with boys and girls in the mathematics classroom. Paper presented at ICME 11, Topic Study Group 32: Gender and mathematics education, Monterrey, México.

Rodriguez, C. \& Ursini, S. (2008). Social representation and gender in the teaching of mathematics with multimedia devices. ICME 11, Topic Study Group 32: Gender and mathematics education, Monterrey, México.

Saavedra, P. (2010). Trayectoria académica de las mujeres matemáticas en México. http://docencia.izt.uam.mx/psb/ciencia.pdf (March 3rd, 2012).

Trigueros, M. \& Lozano, M.D. (2008). Teachers' assessment practices in mathematics courses. Does gender make a difference? ICME 11, Topic Study Group 32: Gender and mathematics education, Monterrey, México.

Ursini, S. (2010). Diferencias de género en la representación social de las matemáticas: Un estudio con estudiantes de secundaria. In N. Blazquez, y F. Flores (Eds.). Investigación feminista. Epistemología, metodología y representaciones sociales. Colección Debate y Reflexión. CEIICH. Facultad de Psicología. UNAM. México.

Ursini, S., Ramírez, M. P., Rodríguez, C., Trigueros, M., and Lozano, M. D. (2010). Studies in Mexico on Gender and Mathematics. In H.J. Forgasz, J. Rossi Becker, K.H. Lee and O. Steinthorsdottir (Eds.) International Perspectives on Gender and Mathematics Education, 7, 147-172.

Ursini, S. \& Sánchez, G. (2008). Gender, technology and attitudes towards mathematics: A comparative longitudinal study with Mexican students. ZDM The International Journal on Mathematic Education. 40, 559-577.

Ursini, S., Ramirez, M. P. \& Sánchez, G. (2007). Using technology in the mathematics class: How this affects students' achievement and attitudes. Proceedings of the 8th ICTMT, (Integration of ICT into Learning Processes). Czech Republic, University of Hradec Králové, [CD-ROM]

Ursini S., Sánchez G., \& Orendain, M. (2004). Validación y confiabilidad de una escala de actitudes hacia las matemáticas y hacia las matemáticas enseñada con computadora. Educación Matemática, 16(3), 59-78.

\title{
Gender and Mathematics in Australia: A Downward Trajectory
}

\author{
Helen J. Forgasz \\ Monash University, Australia \\ e-mail: Helen.forgasz@monash.edu
}




\section{Introduction}

In this paper I draw attention to four areas in which gender equity in mathematics education has yet to be fully achieved in Australia, and where indications are that we are going backwards: (i) achievement in TIMSS and PISA; (ii) participation and achievement in higher level mathematics; (iii) use of technologies for mathematics learning; and (iv) public perceptions of gender issues in mathematics.

\section{Australian Context}

Despite laws and government policy decrying inequity, the realities of gender equity have not yet been fully realized in Australia. This is evident with respect to educational levels, occupations and salaries. Despite higher proportions of women than men having Year 12 or equivalent qualifications, bachelor-level degrees, and higher literacy and numeracy skill levels (Australian Bureau of Statistics 2012), graduate median starting salaries still show a $\$ 2,000$ difference in favor of men, a consistent pattern over the past decade. When it comes to educational pathways leading to career options, males remain dominant in the physical sciences, and females in the humanities and social sciences.

\section{TIMSS and PISA Results}

Australian results in all years of TIMSS and PISA are shown in Table 1. The data reveal a disturbing pattern. Mean scores on TIMSS for grade 4 and grade 8 show an increasing gender gap favoring males, with the 2007 grade 8 score differences reaching statistical significance. For the PISA results, the gender gap in mean scores favors males in all years, but in 2006 and 2009, the score differences were also statistically significant.

Thomson et al. (2011, p. 299) claimed that "the re-emergence of gender difference as shown in PISA since 2006 are a salutary reminder to (Australian) schools and systems that this is still a significant issue and that if Australia is to improve its performance in mathematics, girls' scores must improve".

\section{Participation and Achievement in Grade 12 Mathematics}

The Victorian (Australia) grade 12 mathematics subject enrolment figures reveal a consistent pattern over time. Three mathematics options are offered at grade 12: Specialist Mathematics (most challenging, calculus-based), Mathematical Methods 
Table 1 TIMSS (1995-2007) and PISA (2000-2009) results for Australia

\begin{tabular}{|c|c|c|c|c|}
\hline & TIMSS $1995^{\mathrm{a}}$ & TIMSS 1999 & TIMSS 2003 & TIMSS 2007 \\
\hline \multirow[t]{2}{*}{ Grade 4} & $\begin{array}{l}F=545 \\
M=547\end{array}$ & No Grade 4 & $\begin{array}{l}F=497 \\
M=500\end{array}$ & $\begin{array}{l}F=513 \\
M=519\end{array}$ \\
\hline & $\begin{array}{l}2 \text { points } \\
(\mathrm{M}>\mathrm{F})\end{array}$ & & $\begin{array}{l}3 \text { points } \\
(\mathrm{M}>\mathrm{F})\end{array}$ & $\begin{array}{l}6 \text { points } \\
(\mathrm{M}>\mathrm{F})\end{array}$ \\
\hline \multirow[t]{2}{*}{ Grade 8} & $\begin{array}{l}F=532, \\
M=527\end{array}$ & $\begin{array}{l}F=524 \\
M=526\end{array}$ & $\begin{array}{l}F=499, \\
M=511\end{array}$ & $\begin{array}{l}F=488, \\
M=504\end{array}$ \\
\hline & $\begin{array}{l}5 \text { points } \\
(\mathrm{F}>\mathrm{M})\end{array}$ & $\begin{array}{l}2 \text { points } \\
(\mathrm{M}>\mathrm{F})\end{array}$ & $\begin{array}{l}12 \text { points } \\
(\mathrm{M}>\mathrm{F})\end{array}$ & $\begin{array}{l}16 \text { points } \\
(\mathrm{M}>\mathrm{F})^{*}\end{array}$ \\
\hline \multirow[t]{2}{*}{$\begin{array}{l}\text { Final year of } \\
\text { schooling }\end{array}$} & $\begin{array}{l}F=510, \\
M=540\end{array}$ & & & \\
\hline & $\begin{array}{l}30 \text { points } \\
(\mathrm{M}>\mathrm{F})^{*}\end{array}$ & & & \\
\hline \multirow[t]{3}{*}{15 year olds } & $\begin{array}{l}F=527 \\
M=539\end{array}$ & $\begin{array}{l}F=522, \\
M=527\end{array}$ & $\begin{array}{l}F=513, \\
M=527\end{array}$ & $\begin{array}{l}F=509 \\
M=519\end{array}$ \\
\hline & $\begin{array}{l}12 \text { points } \\
(\mathrm{M}>\mathrm{F})\end{array}$ & $\begin{array}{l}5 \text { points } \\
(\mathrm{M}>\mathrm{F})\end{array}$ & $\begin{array}{l}14 \text { points } \\
(M>F)^{*}\end{array}$ & $\begin{array}{l}10 \text { points } \\
(\mathrm{M}>\mathrm{F})^{*}\end{array}$ \\
\hline & PISA 2000 & PISA 2003 & PISA 2006 & PISA 2009 \\
\hline \multirow[t]{2}{*}{15 year olds } & $\begin{array}{l}F=527 \\
M=539\end{array}$ & $\begin{array}{l}F=522, \\
M=527\end{array}$ & $\begin{array}{l}F=513, \\
M=527\end{array}$ & $\begin{array}{l}F=509 \\
M=519\end{array}$ \\
\hline & $\begin{array}{l}12 \text { points } \\
(M>F)\end{array}$ & $\begin{array}{l}5 \text { points } \\
(\mathrm{M}>\mathrm{F})\end{array}$ & $\begin{array}{l}14 \text { points } \\
(\mathrm{M}>\mathrm{F})^{*}\end{array}$ & $\begin{array}{l}10 \text { points } \\
(\mathrm{M}>\mathrm{F})^{*}\end{array}$ \\
\hline
\end{tabular}

Legend: $F$ female; $M$ male; *statistical significant difference

Data sourced from various IEA, OECD, and Australian Council for Educational Research reports of TIMSS and PISA results

${ }^{\text {a }}$ Gill et al. (2002). Student achievement in England. Results in reading, mathematical and scientific literacy among 15-year-olds from OECD PISA 2000 study (p. 47). London: The Stationery Office (HMSO)

(includes calculus, pre-requisite for many university-level science-related courses), and Further Mathematics (least challenging, with an emphasis on statistics). The data in Fig. 1 reveal that enrolments have declined over time in Specialist mathematics while increasing in Further Mathematics. Yet, consistently, there have been higher proportions of males than females enrolled in all three options.

(a)

(b)

(c)
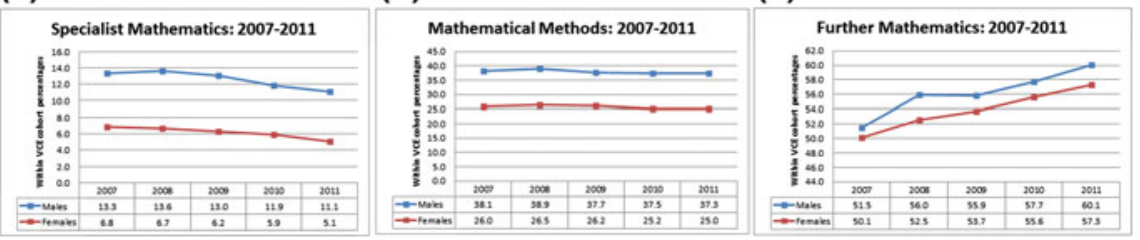

Fig. 1 Enrolment trends 2007-2009 in VCE mathematics subjects 
Table 2 Highest achievers (top $2 \%$ ) in VCE mathematics (2007-2009)

\begin{tabular}{|c|c|c|c|c|c|c|c|}
\hline \multirow[t]{2}{*}{ Subject } & \multirow[t]{2}{*}{ Gender } & \multicolumn{2}{|c|}{$\begin{array}{l}2007 \\
(\mathrm{~N}=65)\end{array}$} & \multicolumn{2}{|c|}{$\begin{array}{l}2008 \\
(\mathrm{~N}=60)\end{array}$} & \multicolumn{2}{|c|}{$\begin{array}{l}2009 \\
(\mathrm{~N}=59)\end{array}$} \\
\hline & & $\mathrm{n}$ & $\%$ & $\mathrm{n}$ & $\%$ & $\mathrm{n}$ & $\%$ \\
\hline \multirow[t]{3}{*}{ Specialist mathematics } & Female & 15 & 23.1 & 14 & 23.3 & 14 & 23.7 \\
\hline & Male & 49 & 75.4 & 44 & 73.3 & 45 & 76.3 \\
\hline & Unknown & 1 & 1.5 & 2 & 3.3 & - & \\
\hline \multirow[t]{3}{*}{ Mathematical methods } & Female & 50 & 25.1 & 53 & 25.7 & 67 & 33.7 \\
\hline & Male & 133 & 66.8 & 150 & 72.8 & 131 & 65.8 \\
\hline & Unknown & 16 & 8.0 & 3 & 1.5 & 1 & 0.5 \\
\hline \multirow[t]{3}{*}{ Further mathematics } & Female & 114 & 36.5 & 114 & 35.5 & 139 & 42.1 \\
\hline & Male & 187 & 59.9 & 205 & 63.9 & 191 & 57.9 \\
\hline & Unknown & 11 & 3.5 & 2 & 0.6 & & \\
\hline
\end{tabular}

An even more disturbing trend is found when the very highest achievers in these three mathematics options are considered, that is, the top $2 \%$. It is found that males outperform females at a rate that is disproportionate to their enrolments in these subjects (see Table 2 for data from 2007 to 2009). The data in Table 2 reveal that more than $50 \%$ of the highest achievers in each of the three VCE subjects were male and that this pattern persisted over the three year period, 2007-2009.

\section{Technologies for Mathematics Learning}

The adoption of computers and calculators in mathematics classrooms has received much research attention in Australasia; less common is research incorporating gender as a variable - see Geiger et al. (2012) for an overview of recent Australasian research. Technology (and ICT), like mathematics, is considered a male domain. Hence, when technology is brought into the mathematics classroom, the effect of this combination with respect to gender issues clearly demands greater research interest than is evident. Researchers examining computer and/or sophisticated calculator use for mathematics learning and gender have found that those who appear to benefit more from the use of the technologies are those who are comfortable with the technology, that is, it is more likely to be boys than girls, but not necessarily boys with the highest mathematical capabilities. Much of the work on mathematics, technology, and gender has focused on the affective domain. Here it is clear that boys' confidence and competence levels with the technologies are more positive than girls', that boys more strongly than girls say they enjoy learning mathematics with technology, and that this is also the expectation of teachers and parents. 


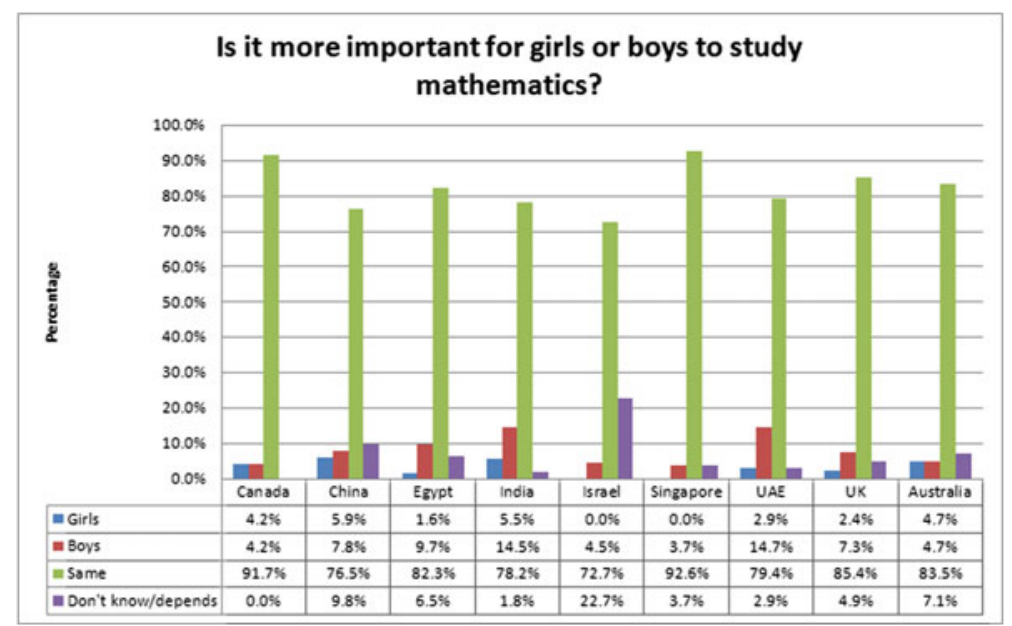

Fig. 2 Response frequency by country: is it more important for girls or boys to study mathematics?

\section{Public Perceptions of Gender Issues in Mathematics}

Early explanatory models for gender differences in mathematics learning incorporated the views of society at large as critical contributing influences. Until recently, however, the views of the general public have rarely been sought. Very recent survey data reveal that the male stereotype is alive and well in the views of the Australian public and elsewhere in the world (e.g., Forgasz et al. 2012).

The extent of the view that mathematics is a male domain varies across the globe. In many countries, a large proportion of respondents to an online survey indicated that it is equally important for boys and girls to study mathematics (see Fig. 2). However, compared to girls, many believed that: boys are better at mathematics (see Fig. 3) and that parents and teachers also believe this, that boys are better with calculators and computers (see Fig. 4), and that boys are more suited to careers in science-related and computer occupational fields. As can be seen in Figs. 2, 3 and 4, Australian respondents' views on these issues fell somewhere between the extremes, with respect to response frequencies.

\section{Final Words}

The picture portrayed in the four brief snapshots above reveal a gendered world of mathematics learning that has changed little over the thirty year period in which research into this area began. The apparent gains made to reduce the gender gap 


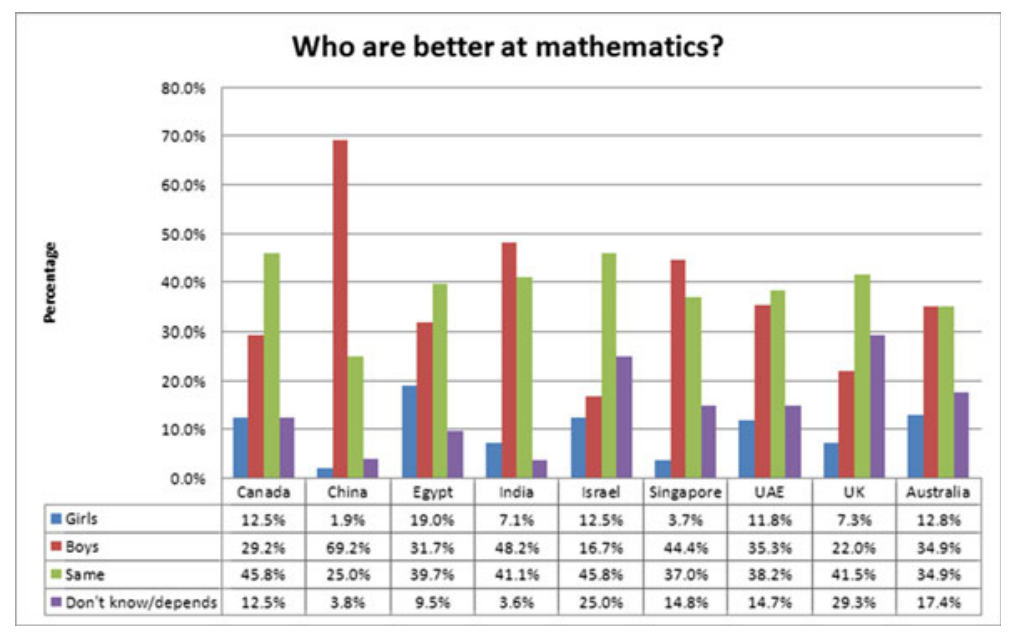

Fig. 3 Response frequency by country: who are better at mathematics?

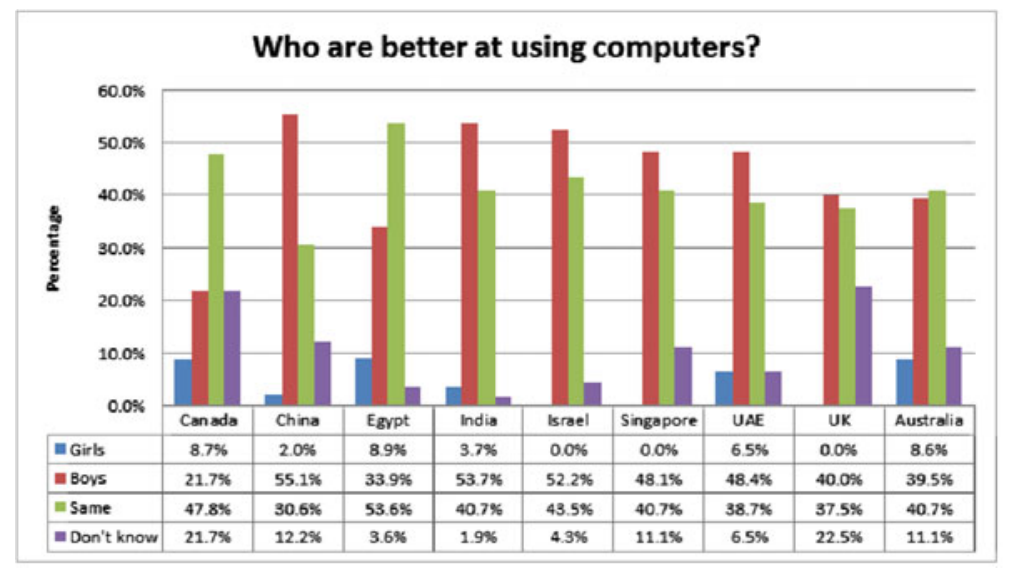

Fig. 4 Response frequency by country: who are better at using computers, girls or boys?

favoring males in participation, achievement, and attitudes during the 1980s and 1990s, appears to have been eroded to the point of a clear backward trajectory emerging in Australia. Believing that there was no longer a "girl problem" with respect to mathematics, with the consequential reduction in vigilance as curricula and practices have changed, may be largely to blame. 


\section{References}

Australian Bureau of Statistics. (2012). Gender indicators, Australia. Retrieved from http://www.abs.gov.au/ausstats/abs@.nsf/mf/4125.0

Forgasz, H., Leder, G., \& Gómez-Chacón, I. (2012, accepted). Young pedestrians' gendering of mathematics: Australia and Spain. Paper accepted for presentation at the annual conference of the Mathematics Education Research Group of Australia, Singapore.

Geiger, V., Forgasz, H., Tan, H., Calder, N., \& Hill, J. (2012). Technology in mathematics education. In B. Perry, T. Lowrie, T. Logan, A. MacDonald, \& J. Greenlees (Eds.), Research in mathematics education in Australasia, 20082011 (pp. 111-142). Rotterdam, The Netherlands: Sense Publishers.

Thomson, S., De Bortoli, L., Nicholas, M., Hillman, K., \& Buckley, S. (2011). PISA in brief. Highlights from the full Australian report: Challenges for Australian education: Results from PISA 2009. Retrieved from http://www.acer. edu.au/documents/PISA-2009-In-Brief.pdf

\section{Taking a European Perspective}

Lovisa Sumpter

School of Education and Humanities, Dalarna University, Sweden

e-mail: 1sm@du.se

\section{Taking a European Perspective}

In this paper I look at how gender and mathematics education has been studied in Europe with the aim of highlighting trends but also discussing emerging themes. The main question posed in this paper is: What research focus in gender and mathematics can we find in papers that have been published during the years of 2007-2011? Gender is here defined as an "analytic category which humans think about and organize their social activity rather than as a natural consequence of sex difference" (Harding 1986, p. 17), emphasizing gender as something individuals do and create rather than something you have as a person. In order to talk about different foci of research on gender and mathematics, I follow Bjerrum Nielsen (2003) and use the following four aspects of gender: (1) structural gender, e.g. research of different groups within structures such as professions, level of education or social background; (2) symbolic gender e.g. studies looking at symbols and discourses that are attributed to a specific gender creating norms telling us what is normal and what is deviant; (3) personal gender e.g. studies on how girls and boys feel or think about various items or studies looking at individual's development of 
gender; and, (4) interactional gender e.g. research looking at how people interact with each other or how the social context is created. By using these four aspects different parts of the concept 'gender' can be emphasized.

\section{Method}

The data that constitute the base for the analysis were generated from the ERIC database, February 2012. The search terms were 'mathematics' and 'gender', peerreviewed journal articles published within the last 5 years. By choosing only mathematics and not 'math' or 'maths' some papers were inevitably not included. The number of papers resulting from this search was 585. Thereafter I classified what could be considered European research; defined here as data collected in at least one European country, although the author/s could be positioned in any country. The list was narrowed down to 181 papers. Using Harding's (1986) definition of gender means that I have excluded all papers only using gender to denote division of sex, e.g. studies looking at sex-differences in performance (total 51 papers). I also excluded papers not on mathematics (e.g. using mathematics as a notion of intelligence or focusing on another subject e.g. chemistry, 23 papers) and papers that have a general international scope (11 papers). Most papers within this category were large-scale comparisons, e.g. results from international tests. Finally, four papers (all from Turkey) were not available online and therefore could not be analyzed. This left a total of 92 papers. The papers were divided into the four categories. If a paper dealt with multiple aspects, the main focus was selected. This is a simple division and it should be stressed that most papers are more complex and touch several aspects either in the background to the study, factors in the analysis and/or in the discussion of results. However, this division provided information for discussing main trends and themes.

\section{Results and Discussion}

The results were summarized in tables. Table 3 shows the number of papers produced by the different European countries in alphabetical order and the aspect of gender.

One paper has been marked as 'Europe' since the focus of the paper was evenly distributed among the participating countries; Garcia-Aracil (2008) compared college major and earning gaps in seven European countries. The countries that produced most papers during this period are UK and Germany followed by Finland. There are differences between the countries in which aspects of gender have been studied. Papers from UK, Finland, Sweden and Israel covered all aspects of gender whereas there was no paper focusing on interactional gender from Germany or Turkey. Looking closer at the papers from Germany, all of them were quantitative 
Table 3 Aspect of gender and number of papers by country

\begin{tabular}{l|l|l}
\hline Country & Number & Gender aspect \\
\hline Europe $^{\mathrm{a}}$ & 1 & 1 \\
\hline Belgium & 2 & 1,1 \\
\hline Croatia & 1 & 3 \\
\hline Cyprus & 1 & 1 \\
\hline Estonia & $0.5^{\mathrm{b}}$ & 4 \\
\hline Finland & $12.5^{\mathrm{b}}$ & $1,1,1,1,1,2,2,2,3,3,3,4,4$ \\
\hline France & 3 & $2,3,3$ \\
\hline Germany & 16 & $1,1,2,2,2,2,2,2,3,3,3,3,3,3,3,3$ \\
\hline Greece & 1 & 3 \\
\hline Iceland & 2 & 1,1 \\
\hline Ireland & 2 & 1,3 \\
\hline Israel & 5 & $1,1,2,3,4$ \\
\hline Italy & 2 & 2,2 \\
\hline The Netherlands & 7 & $1,1,1,3,3,3,3$ \\
\hline Norway & 2 & 1,1 \\
\hline Spain & 3 & $2,3,3$ \\
\hline Sweden & 6 & $1,1,2,3,3,4$ \\
\hline Turkey & 7 & $1,1,1,2,2,3,3$ \\
\hline UK & 17 & $1,1,1,2,3,3,3,3,3,3,3,3,3,3,3,4,4$ \\
\hline Note The num &
\end{tabular}

Note The number of papers is 92

${ }^{\text {a }}$ Seven European countries

${ }^{\mathrm{b}}$ Comparative study Finland and Estonia

${ }^{\mathrm{c}}$ Gender aspect: 1 structural; 2 symbolic; 3 personal; 4 interactional

studies, often large-scale, and most of them (10 of 12) were published in a journal not specific for mathematics education.

Let us look at the main focus of the selected papers. This is the number of papers covering different aspects of gender: structural, 30 papers (33\%); symbolic, 18 papers $(20 \%)$; personal, 38 papers $(41 \%)$; interactional, 6 papers $(7 \%)$. Most papers focused on structural gender or personal gender, whereas only six papers were on interactional gender. What these six papers have in common is that all of them looked at people's conceptions in relation to each other or to a development, e.g. Francis (2008) who studied interactions in different classes, where one of the classes presented is a math class. The majority of papers in structural and symbolic gender were quantitative studies, e.g., Ammann et al. (2010) who studied the number of students enrolled in undergraduate mathematics courses and Räty and Kärkkainen (2011) who looked at parents' stereotyping. We find a bigger variation of methods for data collection moving to the category 'personal gender', e.g. Mendick (2008) who used interviews when studying two students' conceptions about transitions between levels. Four papers focused on mathematics at preschool level. Klein et al. (2010) studied pre-school teachers' attributions of children's achievements in mathematics, and Ojala and Talts (2007) looked at pre-school 
teachers' evaluations of achievements. Palmer (2009, 2010) studied pre-school teacher education when writing about alternative mathematical practices.

As mentioned earlier, German papers were mainly found in non-mathematics education journals. This seemed to be a general trend. The top five journals in terms of publications relevant for this review were: British Educational Research Journal, 7 papers (8\%); European Journal Psychology Education, 5 papers (5\%); Gender and Education, 5 papers (5\%); International Journal of Mathematical Education in Science and Technology, 5 papers (5\%); Scandinavian Journal of Educational Research, 4 papers (4\%). The discussion about mathematics and gender mainly took place in journals that do not aim specifically towards mathematics education.

With respect to selecting areas for future research, the first topic I see as an emerging theme is research focusing on interactional gender. Four of the six papers on this aspect were published in 2010, possibly indicating an upcoming topic. Overall, there were few studies looking at "doing gender" in educational settings compared to the number of papers studying people "having gender". The most common type of paper was one reporting a large-scale quantitative study focusing on conceptions of different kinds, often related to mathematical achievement. Very few projects drew on qualitative measures in order to find out more about what 'doing gender' implies at various levels. Also, not many papers had a strong mathematical focus. A second theme for future is research looking at more content specific issues. The third area I see as an area that as yet has not been addressed in detail is research focusing on children under the age of five. There were only four papers aiming at pre-school mathematics, but not a single paper focused on preschool students themselves. If we are to understand how personal gender is constructed, we need to know more about the process from the very beginning.

\section{References}

Ammann, C., Frauendiener, J. \& Holton, D. (2010). German undergraduate mathematics enrolment numbers: background and change. International Journal of Mathematical Education in Science and Technology, 41(4), 435-449

Bjerrum Nielsen, H. (2003). One of the boys? Doing gender in Scouting. Génève: World Organization of the Scout Movement.

Francis, B. 2010. Re/theorising gender: Female masculinity and male femininity in the classroom? Gender and Education, 22 (5), 477-490.

Garcia-Aracil, A., (2008). College major and the gender earnings gap: a multicountry examination of postgraduate labour market outcomes. Research in Higher Education 49, 733-757.

Harding, S. (1986). The Science Question in Feminism. Ithica, NY: Cornell University Press.

Klein, P.S., Adi-Japha, E., \& Hakak-Benizri, S. (2010). Mathematical thinking of kindergarten boys and girls: similar achievement, different contributing process. Educational Studies in Mathematics, 73, 233-246. 
Mendick, H. (2008). Subtracting difference: troubling transitions from GCSE to AS-level mathematics. British Educational Research Journal 34 (6). 711-732.

Ojala, M., \& Talts, L. (2007). Preschool achievement in Finland and Estonia: Cross-cultural comparison between the cities of Helsinki and Tallinn. Scandinavian Journal of Educational Research 51(2), 205-221.

Palmer, A. (2009). "I'm not a "maths-person"! Reconstituting mathematical subjectivities in aesthetic teaching practices. Gender and Education 21(4), 387-404.

Palmer, A. (2010). 'Let's dance!' Theorising alternative mathematical practices in earlychildhood teacher education. Contemporary Issues in Early Childhood 11 (2), 130-143.

Räty, H. \& Kärkkainen, R. (2011). Are parents' academic gender stereotypes and changes in them related to their perceptions of their child's mathematical competence? Educational Studies, 37(3), 371-374.

\title{
Gender and Mathematics Education in the United States
}

\author{
Sarah Lubienski \\ University of Illinois at Urbana-Champaign, USA \\ e-mail: stl@illinois.edu
}

\section{Introduction}

Over the past several decades, the United States has made considerable progress toward gender equity in education. Substantial achievements have been made, such as the closure of gender gaps in high school mathematics course taking and college attendance (Lacampagne et al. 2007). In fact, some U.S. writers now argue that girls are more advantaged than boys, given that girls tend to score higher in reading, get better grades in school, and complete more bachelor degrees (e.g., Sommers 2000). However, gaps remain in mathematics achievement, affect, and ultimately the pursuit of high-status STEM careers.

\section{Achievement}

U.S. gender disparities in secondary mathematics achievement generally favor boys and are similar in size to those of many other industrialized nations (Else-Quest et al. 2010; OECD). However, TIMSS data suggest that significant mathematics score gaps favoring boys occur earlier in the U.S. than in most participating countries 
(Mullis et al. 2008). Most recently, studies using data from the U.S. Early Childhood Longitudinal Study (ECLS), indicate that U.S. boys' and girls' mathematics proficiency is similar at the start of school (roughly age 5), but a significant male advantage emerges by age 8 (Robinson and Lubienski 2011). Regardless of grade level or dataset, U.S. mathematics gender gaps tend to be largest at the upper end of the achievement distribution (McGraw et al. 2006; Robinson and Lubienski 2011).

\section{Affect}

As in most countries participating in TIMSS and PISA, girls in the U.S. report having substantially less mathematical confidence than boys (Else-Quest et al. 2010). Recent analyses of ECLS data reveal that this trend exists already in U.S. primary schools, with gaps in confidence being substantially larger than gaps in both actual performance and interest in mathematics. Moreover young students' confidence predicts later gains in both mathematics achievement and interest (Lubienski et al. 2012).

\section{Careers}

Although women in the U.S. are at least as likely as men to pursue many sciencerelated careers (e.g., biology), women remain under-represented in higher-paying, mathematics-intensive fields, such as engineering and computer science, in which women earn less than $20 \%$ of bachelor's degrees (Snyder and Dillow 2011). These career patterns are a primary factor underlying earnings disparities among male and female college graduates, with U.S. women earning only $69 \%$ of comparable men's salaries (Dey and Hill 2007).

\section{Teachers and Students}

U.S. girls are more compliant than boys in school (Rathbun et al. 2004), and boys are more likely than girls to exhibit a performance goal orientation, striving to "show off" their knowledge (Kenney-Benson et al. 2006). These patterns could cause boys to use more bold, invented methods during problem solving and could shape teachers' and students' views of who is "smart" (Fennema et al. 1998). Past research has revealed ways in which U.S. teachers attend more to boys than to girls (Sadker and Sadker 1986), and to attribute boys' mathematics success to ability and girls' success to effort (Fennema et al. 1990). More recent research reveals that U.S. elementary teachers rate boys' proficiency in mathematics - but not in reading- 
higher than that of girls with equal test scores and similar classroom behavior (Robinson et al. 2012).

\section{The Field of Mathematics}

Recent research highlights subtle barriers to women's participation in mathematical fields. Lacampagne et al. (2007) emphasize the importance of women having a sense of belonging in mathematics, good relationships with faculty, flexibility in negotiating family responsibilities, and mathematical confidence. However, U.S. males remain more confident of their mathematical abilities relative to females with equal test scores (Correll 2001). Given that the opposite is true for reading, societal views about mathematics and gender likely influence students' perceptions of their own abilities.

\section{Lingering Questions}

The findings summarized thus far raise several questions. For example, why do girls report less mathematical confidence than their achievement merits? Why do U.S. teachers under-rate girls' competence in mathematics but not in literacy, relative to boys with similar behavior and achievement? (Robinson et al. 2012).

And finally, why do gaps in mathematics-related STEM fields remain so substantial despite the closure of key gaps in U.S. mathematics course-taking and college mathematics majors? One U.S. study provides an interesting insight. Males were nearly four times as likely to choose a quantitative college major than females with equal mathematics achievement, but this pattern was largely due to women's relatively strong verbal abilities (Correll 2001). In other words, women had other options, consistent with Eccles' (1986) argument that women make reasoned choices and do not simply avoid math. Interventions could fruitfully target girls' knowledge about ways in which a combination of mathematics and verbal skills could be a powerful asset in meaningful, STEM-related careers.

\section{A Final Word About Research Methods for Studying Gender and Mathematics}

The findings synthesized above are from a wide variety of qualitative and quantitative studies. Given the continued development of more sophisticated statistical methods, as well as the availability of large-scale, longitudinal datasets containing hundreds of variables, quantitative research on gender can go far beyond simply 
confirming the persistence of gaps in mathematics performance (Lubienski 2008). However, qualitative studies are continually needed to explore the factors underlying relationships found in large-scale data, as well as to develop the most important variables to be added to future, large-scale efforts.

\section{References}

Correll, S. J. (2001). Gender and the career choice process: The role of biased selfassessments. American Journal of Sociology, 106(6), 1691-1730.

Dey, J.G. \& Hill, C. (2007). Beyond the pay gap. Washington, DC: American Association of University Women Educational Foundation.

Eccles, J.S. (1986). Gender-roles and women's achievement. Educational Researcher, 15(6), 15- 19.

Else-Quest, N.M., Hyde, J.S., \& Linn, M.C. (2010). Cross-national patterns of gender differences in mathematics: A meta-analysis. Psychological Bulletin, 136 (1), 101-127.

Fennema, E., Carpenter, T. P., Jacobs, V. R., Franke, M. L., \& Levi, L. W. (1998). A longitudinal study of gender differences in young children's mathematical thinking. Educational Researcher, 27(5), 6-11.

Fennema, E., Peterson, P. L., Carpenter, T. P., \& Lubinski, C. A. (1990). Teachers' attribution and beliefs about girls, boys, and mathematics. Educational Studies in Mathematics, 21, 55-69.

Kenney-Benson, G.A., Pomerantz, E.M., Ryan, A.M., \& Patrick, H. (2006). Sex differences in math performance: The role of children's approaches to schoolwork. Developmental Psychology, 42(1), 11-26.

Lacampagne, C. B., Campbell, P. B., Herzig, A. H., Damarin, S., \& Vogt, C. M. (2007). Gender equity in mathematics. In S. S. Klein (Ed.), Handbook for achieving gender equity through education (2nd ed., pp. 235-252). Florence, KY: Taylor and Francis.

Lubienski, S. T. (2008). On "gap gazing" in mathematics education: The need for gaps analyses. Journal for Research in Mathematics Education, 39(4), 350-356.

Lubienski, S. T., \& Ganley, C., \& Crane, C. (2012). Unwarranted uncertainty: Gender patterns in early mathematical confidence, interest and achievement. Paper to be presented at the American Educational Research Association, Vancouver.

McGraw, R., Lubienski, S. T., \& Strutchens, M. E. (2006). A closer look at gender in NAEP mathematics achievement and affect data: Intersections with achievement, race and socio-economic status. Journal for Research in Mathematics Education, 37(2), 129-150.

Mullis, I. V. S., Martin, M. O., \& Foy, P. (2008). TIMSS 2007 international mathematics report. Chestnut Hill, MA: Boston College. 
Organisation for Economic Co-operation and Development. (2009). Equally prepared for life? How 15-year-old boys and girls perform in school. Paris, France: Author.

Rathbun, A. H., West, J., \& Germino-Hausken, E. (2004). From kindergarten through third grade: Children's beginning school experiences (NCES 2004007). Washington, DC: National Center for Education Statistics.

Robinson, J.P., \& Lubienski, S.T. (2011). The development of gender achievement gaps in mathematics and reading during elementary and middle school: Examining direct cognitive assessments and teacher ratings. American Educational Research Journal, 48(2), 268-302.

Robinson, J. P., Lubienski, S. T., \& Copur-Gencturk, Y. (2012). Gender-biased perceptions fuel early mathematics gender gap. Paper to be presented at the American Educational Research Association, Vancouver.

Sadker M., \& Sadker, D. (1986). Sexism in the classroom: From grade school to graduate school. Phi Delta Kappan, 68, 512-515.

Sommers, C. H. (2000). The war against boys: How misguided feminism is harming our young men. New York, NY: Touchstone Books.

Snyder, T. D. \& Dillow, S. A. (2011). Digest of Education Statistics 2010 (NCES 2011-015). National Center for Education Statistics, Institute of Education Sciences, U.S. Department of Education. Washington DC.

\title{
Panel on "Gender and Mathematics Education Revisited"-Final Comments
}

\author{
Gilah C. Leder \\ Monash University, Australia \\ e-mail: Gilah.Leder@monash.edu
}

\begin{abstract}
In our culture ... being "good in math" is 'being bright', and being bright in mathematics is associated with control, mastery, quick understanding, leadership. Unsuccessful mathematics implies the opposite ... (Reisman and Kaufman 1980, p. 36)
\end{abstract}

The journey into the field of gender and mathematics education provided by the panelists served as a return visit to the field for some of the audience but signified a new, previously untraveled journey for others. Given the importance in many countries attached to mathematics, it is an intellectual journey well worth the effort. So what have we learnt?

Irrespective of the theoretical stance taken, it seems that there is considerable commonality in the external factors likely to facilitate or impede the pathway towards achieving gender parity and gender equality: the cultural, social, political and economic environments, systemic factors, historical precedents and community expectations. 
Similarities permeate the different presentations. Despite decades of research it seems that evidence is still found of subtle but consistent gender differences in favor of males, particularly in mathematics performance and participation in post compulsory and advanced mathematics courses, on selected mathematical tasks on standardized or large scale tests, and among high performing students.

Some of the special interventions introduced in Western countries to redress demonstrated achievement disparities in mathematics learning have been taken up more widely, directly or with realistic adaptations.

Unanticipated between country differences were also reported. For example, research from Mexico suggested that girls are advantaged by technology—a finding not replicated in Australia. Perceptions (by the public in Australia) that teachers believe boys and girls are equally good at mathematics are seemingly at variance with reports from the USA that teachers rate boys and girls differently with respect to mathematics achievement.

Clearly, challenges remain before the goals of gender parity and gender equality are achieved, or even principally achieved, in an enlarged number of countries. The more modest goal of improved access for all, including females, to mathematics learning also remains elusive.

Constructive and contextually relevant recommendations have been made in the various panel presentations. The claim that "feminism has made its greatest contributions by asking new questions, often at odds with fundamental assumptions in a discipline" (Schiebinger 2001, p. 187) provokes a set of further questions which sharpen areas worthy of renewed and careful scrutiny. For example: Who, in our different countries, decides who should benefit from education; what mathematics should be taught, and to whom? Who determines educational and scientific priorities promoted for short and longer term funding? These are among practical starting points. For any changes in the current answers to be achieved, followed by constructive practical interventions, close cooperation between individuals and organizations is required. How well this challenge is met warrants careful and persistent monitoring.

\section{References}

Reisman, F. K., \& Kauffman, S. (1980). Teaching mathematics to children with special needs. Columbus, OH: Charles E. Merrill Publishing Company.

Schiebinger, L. (2001). Has feminism changed science? Cambridge, Massachusetts: Harvard University Press.

Open Access This chapter is distributed under the terms of the Creative Commons Attribution Noncommercial License, which permits any noncommercial use, distribution, and reproduction in any medium, provided the original author(s) and source are credited. 